\title{
Heavy Metal Concentrations in Tin Mine Effluents in Kepayang River, Perak, Malaysia
}

\author{
Farhana Ahmad Affandi and Mohd Yusoff Ishak* \\ Department of Environmental Management, Faculty of Environmental Studies, \\ Universiti Putra Malaysia, 43400 UPM Serdang, Selangor, Malaysia \\ *Corresponding author: m_yusoff@upm.edu.my
}

Published online: 25 October 2018

To cite this article: Ahmad Affandi, F. \& Ishak, M. Y. (2018). Heavy metal concentrations in tin mine effluents in Kepayang River, Perak, Malaysia. J. Phys. Sci., 29(Supp. 3), 81-86, https://doi.org/10.21315/jps2018.29.s3.10

To link to this article: https://doi.org/10.21315/jps2018.29.s3.10

\begin{abstract}
A preliminary study on physico-chemical properties and heavy metal concentrations, i.e., aluminium (Al), arsenic (As), barium (Ba), cadmium (Cd), cobalt (Co), copper (Cu), chromium (Cr), iron (Fe), manganese (Mn), nickel (Ni), lead (Pb), selenium (Se) and zinc ( $\mathrm{Zn})$, was conducted at the nearest point of tin mine effluents in Kepayang River, Perak, Malaysia. Composite samples of surface water and sediments were analysed using inductively coupled plasma mass spectrometry (ICP-MS) and data were compared with the Malaysia's Ministry of Health (MOH) and the Canadian Council of Ministers of the Environment (CCME) guidelines. The concentrations of As and Fe in both water and sediment were found to have exceeded the MOH and CCME guidelines. The output from this study can present as a background report on metal concentrations of tin mine effluents, which will be useful for future monitoring works.
\end{abstract}

Keywords: Heavy metals, sediment, tin mine effluent, water, metal concentrations

\section{INTRODUCTION}

Tin mining is one of the oldest industries in Malaysia. The exploitation of tin ores due to demand has led to uncontrolled mining activities. These activities have caused serious environmental problems such as deterioration of mining land and river water quality. Previous studies in Malaysia showed mining as a major source of heavy metal contaminations in the water. ${ }^{1,2}$ Rahman Hydraulic Tin (RHT) Sdn. Bhd. is known to be the largest tin mining company in Malaysia that has been operating in the upper stream area of Kepayang River, Perak, Malaysia since 1907 
and is still active. ${ }^{3}$ However, over the last few years, lower water quality has been reported downstream, which has caused a decline in the volume of fishes catched in the connected Rui River. ${ }^{4}$

Elevated levels of heavy metals due to mining have been reported to pollute the natural aquatic environments in Malaysia. ${ }^{5,6}$ Most of the studies on tin mines in Malaysia only focused on ex-mining areas, and very rarely cover active mines..$^{1,2}$ Therefore, this preliminary study attempts to provide data on the metal contents in mine effluents from RHT that has been released into the Kepayang River, so that appropriate action or research can be taken to monitor any hazardous effects on the water and biodiversity downstream.

\section{EXPERIMENTAL}

RHT is located at the upper stream of Kepayang River ( $5^{\circ} 38^{\prime} 5.79^{\prime \prime} \mathrm{N} 101^{\circ} 1^{\prime}$ 40.79" E) in Klian Intan, Perak, in the northern part of Peninsular Malaysia. Kepayang River is one of the small tributaries of Rui River, which transports any waste or pollutants from the RHT mine into the main Perak River. Composite samples of surface water and sediments were collected in May 2016 at the last point of RHT's settling pond $\left(2400 \mathrm{~m}^{2}\right)\left(5^{\circ} 36^{\prime} 11.2^{\prime \prime} \mathrm{N} 101^{\circ} 2^{\prime} 50.5^{\prime \prime} \mathrm{E}\right)$, where the mine waste is being treated with limestone, before released into the Kepayang River. The water sample was stored in an acid-washed polyethylene bottle and acidified with concentrated $\mathrm{HNO}_{3}$ to a $\mathrm{pH}<2$. Meanwhile, the sediment sample was collected using a plastic scoop and stored in an acid-washed polyethylene bag. Both samples were then transported to the laboratory at $4^{\circ} \mathrm{C}$ until analysis.

The in-situ water quality parameters such as $\mathrm{pH}$, temperature, electrical conductivity (EC), salinity, dissolved oxygen (DO) and turbidity were measured on site using Thermo Orion $\mathrm{pH}$ portable, Thermo Orion conductivity portable, YSI $52 \mathrm{DO}$ meter and Hach 2100P Turbidimeter, respectively. For metal analysis, the water samples were filtered through a $0.45 \mu \mathrm{m}$ cellulose acetate membrane filter and analysed for total dissolved metals of aluminum (Al), arsenic (As), barium (Ba), cadmium (Cd), cobalt $(\mathrm{Co})$, copper $(\mathrm{Cu})$, chromium $(\mathrm{Cr})$, iron $(\mathrm{Fe})$, manganese $(\mathrm{Mn})$, nickel $(\mathrm{Ni})$, lead $(\mathrm{Pb})$, selenium $(\mathrm{Se})$ and zinc $(\mathrm{Zn})$, using inductively coupled plasma mass spectrometry (ICP-MS, Perkin Elmer, ELAN DRC-e).

The $\mathrm{pH}$ of sediments was measured according to McLean. ${ }^{7}$ The sediment EC was measured following Eigenberg et al. ${ }^{8}$ For metals, the sediment samples were ovendried at $60^{\circ} \mathrm{C}$ for $48-72 \mathrm{~h}$, then meshed and sieved $(63 \mu \mathrm{m})$. About $1 \mathrm{~g}$ of the dried sediment was digested in a $10 \mathrm{ml}$ solution of a mixture of $\mathrm{HNO}_{3}$ and $\mathrm{HClO}_{4}$ in the 
ratio of $4: 1(\mathrm{v} / \mathrm{v})$ into a block digester at a low temperature $\left(40^{\circ} \mathrm{C}\right)$ for $1 \mathrm{~h}$ and then at $140^{\circ} \mathrm{C}$ for $3 \mathrm{~h} .{ }^{9}$ The digested sample was then diluted to $100 \mathrm{ml}$ with Milli-Q (Millipore, United States) water and filtered through a $0.45 \mu \mathrm{m}$ cellulose acetate membrane filter before being measured using ICP-MS.

Reagents used in the present study were of analytical grade. All apparatus and glassware were soaked in $10 \% \mathrm{HNO}_{3}$ for at least $24 \mathrm{~h}$ and rinsed with distilled water. Triplicate samples were tested for each composite sample. Statistical analysis was conducted using MS Excel 2010 software. Data on both water and sediment were compared to guidelines from the Ministry of Health $(\mathrm{MOH})$ Malaysia for raw and drinking water, and Canadian Council of Ministers of the Environment (CCME) for industrial soil and aquatic life sediment, respectively.

\section{RESULTS AND DISCUSSION}

Based on the results (Table 1), the $\mathrm{pH}$ of both water and sediment were within the range values of the $\mathrm{MOH}$ and CCME guidelines. Previous studies showed that water draining from mining activities are usually in acidic condition. ${ }^{10}$ However, in this present study, the $\mathrm{pH}$ values of both water and sediment were nearly neutral which may be due to the limestone treatment applied to the settling pond upstream on the same day of sampling. According to Edokpayi et al., mining activities can also attribute to the high levels of $\mathrm{EC}$, and levels greater than $700 \mu \mathrm{S} \mathrm{cm}^{-1}$ may cause negative impacts on aquatic organisms. ${ }^{11}$ Therefore, the EC of water in the present study was considered high with a value of $945 \mu \mathrm{S} \mathrm{cm}^{-1}$.

This study also found that $\mathrm{Fe}, \mathrm{Mn}, \mathrm{As}, \mathrm{Al}$ and $\mathrm{Ni}$ concentrations have exceeded the recommended $\mathrm{MOH}$ guidelines with mean concentrations of $5.679 \mathrm{mg} \mathrm{l}^{-1}$, $4.673 \mathrm{mg} \mathrm{l}^{-1}, 0.288 \mathrm{mg} \mathrm{l}^{-1}, 2.750 \mathrm{mg} \mathrm{l}^{-1}$ and $0.106 \mathrm{mg} \mathrm{l}^{-1}$, respectively. Meanwhile, in the sediment sample, the mean concentrations of $\mathrm{Fe}, \mathrm{As}, \mathrm{Cu}$ and $\mathrm{Pb}$ were found to have exceeded the recommended CCME guidelines with mean values of $14526.73 \mathrm{mg} \mathrm{kg}^{-1}, 1038.10 \mathrm{mg} \mathrm{kg}^{-1}, 94.48 \mathrm{mg} \mathrm{kg}^{-1}$ and $149.34 \mathrm{mg} \mathrm{kg}^{-1}$, respectively. Overall, the tin mine effluent was responsible for the elevated concentration of As and $\mathrm{Fe}$ in both water and sediment of the Kepayang River. This result is supported by Johnson and Hallbergalthough who reported that elevated concentrations of metals such as $\mathrm{Al}, \mathrm{As}, \mathrm{Fe}$ and $\mathrm{Mn}$ are related to acid mine drainage from mining activities. $^{10}$ 
Table 1: Mean concentrations of physico-chemical properties and heavy metals in surface water ( $\left.\mathrm{mg} \mathrm{l}^{-1}\right)$ and sediment ( $\mathrm{mg} \mathrm{kg}^{-1}$, dry weight) of tin mine effluent at Kepayang River.

\begin{tabular}{|c|c|c|c|c|c|c|}
\hline & Water & Sediment & $\begin{array}{l}\text { Raw water } \\
\text { standards }\end{array}$ & $\begin{array}{l}\text { Drinking } \\
\text { water } \\
\text { standards }^{\mathrm{a}}\end{array}$ & $\begin{array}{l}\text { Industrial } \\
\text { soil }^{\text {b }}\end{array}$ & $\begin{array}{l}\text { Predicted } \\
\text { effect level }\end{array}$ \\
\hline $\mathrm{pH}$ & 7.13 & 6.50 & $5.50-9.00$ & $6.50-9.00$ & $6.00-8.00$ & - \\
\hline $\mathrm{EC}\left(\mu \mathrm{S} \mathrm{cm}^{-1}\right)$ & 945 & 301 & - & - & 4000 & - \\
\hline Salinity (ppt) & 0.50 & 0.10 & - & - & - & - \\
\hline $\begin{array}{l}\text { Temperature } \\
\left({ }^{\circ} \mathrm{C}\right)\end{array}$ & 32.33 & - & - & - & - & - \\
\hline Turbidity (NTU) & 65.47 & - & 1000.00 & 5.00 & - & - \\
\hline $\mathrm{DO}\left(\mathrm{mg}^{-1}\right)$ & 6.99 & - & - & - & - & - \\
\hline $\mathrm{Al}$ & 2.750 & 4844.290 & - & 0.200 & - & - \\
\hline As & 0.288 & 1038.100 & 0.010 & 0.010 & 12.000 & 17.000 \\
\hline $\mathrm{Ba}$ & 0.111 & 223.410 & - & - & 2000.000 & - \\
\hline $\mathrm{Cd}$ & 0.001 & 0.480 & 0.003 & 0.003 & 22.000 & 3.530 \\
\hline Co & 0.089 & 20.340 & - & - & - & - \\
\hline $\mathrm{Cr}$ & $*$ & 7.40 & 0.05 & 0.05 & 87.000 & 90.00 \\
\hline $\mathrm{Cu}$ & 0.102 & 94.480 & 1.000 & 1.000 & 91.000 & 197.000 \\
\hline $\mathrm{Fe}$ & 5.679 & 14526.730 & 1.000 & 0.300 & 300.000 & - \\
\hline $\mathrm{Mn}$ & 4.673 & 289.340 & 0.200 & 0.100 & - & - \\
\hline $\mathrm{Ni}$ & 0.106 & 19.910 & - & 0.020 & 89.000 & 36.000 \\
\hline $\mathrm{Pb}$ & 0.001 & 149.340 & 0.050 & 0.010 & 600.000 & 91.300 \\
\hline $\mathrm{Se}$ & 0.001 & 1.440 & 0.010 & 0.010 & - & - \\
\hline $\mathrm{Zn}$ & 0.057 & 39.780 & 3.000 & 3.000 & 360.000 & 315.000 \\
\hline
\end{tabular}

${ }^{a} \mathrm{MOH}, 2010 ;{ }^{b} \mathrm{CCME}, 2015 ;-$ not specified; * below detection limit

\section{CONCLUSION}

This study has revealed that As and Fe are the major metal contaminants in the Kepayang River, Perak, Malaysia coming from a tin mine company located in the upper stream of the river. Therefore, future monitoring works and treatment should be taken by the mining company and government in order to protect the environment. 


\section{ACKNOWLEDGEMENTS}

This study was supported by the Fundamental Research Grant Scheme (FRGS) Vot No: 5524759 awarded by Ministry of Higher Education Malaysia. The authors would also like to acknowledge technical assistance from the staffs of the Department of Fisheries Malaysia and the Faculty of Environmental Studies, Universiti Putra Malaysia (UPM).

\section{REFERENCES}

1. Ahmad, A. K. \& Sarah, A. A.-M. (2014). Assessment of abandoned mine impacts on concentrations and distribution of heavy metals in surface sediments of catchments around Sungai Lembing abandoned tin mine. Iran. J. Energy Environ., 5(4), 453-460.

2. Orji, K. U. et al. (2014). Water quality assessment of ex-mining lakes in Perak, Malaysia as alternative source of water supply. Appl. Mech. Mater., 567, 177-182, https://doi.org/10.4028/www.scientific.net/AMM.567.177.

3. Pengkalan Hulu District Council (PHDC). (2016). Rahman Hydraulic Tin ore mine. Retrieved 27 December 2016 from http://www.mdph.gov.my/en/ visitors/places-interest/rahman-hydraulic-tin-ore-mine.

4. Bernama. (2015). Ikan loma diancam sisa perlombongan. Sinar Harian, 22 September. Retrieved 10 April 2016 from http://www.sinarharian.com.my/ rencana/ikan-loma-diancam-sisa-perlombongan-1.433647.

5. Ashraf, M. A. et al. (2011). Sand mining effects, causes and concerns: A case study from Bestari Jaya, Selangor, Peninsular Malaysia. Sci. Res. Essays, 6(6), 1216-1231.

6. Kusin, F. M. et al. (2016). The occurrence and potential ecological risk assessment of bauxite mine-impacted water and sediments in Kuantan, Pahang, Malaysia. Environ. Sci. Pollut. Res., 24(2), 1306-1321, https://doi. org/10.1007/s11356-016-7814-7.

7. McLean, E. O. (1982). Soil pH and lime requirement. In Page, A. L. (Ed). Methods of soil analysis. Part 2: Chemical and microbiological properties. Madison: American Society of Agronomy, Soil Science Society of America, 199-224.

8. Eigenberg, R. A. et al. (2002). Electrical conductivity monitoring of soil condition and available $\mathrm{N}$ with animal manure and a cover crop. Agric. Ecosyst. Environ., 88(2), 183-193, https://doi.org/10.1016/S01678809(01)00256-0. 
9. Ismail, A. (1993). Heavy metal concentrations in sediments off Bintulu, Malaysia. Mar. Pollut. Bull., 26(12), 706-707, https://doi.org/10.1016/0025326X(93)90556-Y.

10. Johnson, D. B. \& Hallberg, K. B. (2005). Acid mine drainage remediation options: A review. Sci. Total Environ., 338(1-2), 3-14, https://doi. org/10.1016/j.scitotenv.2004.09.002.

11. Edokpayi, J. N., Odiyo, J. O. \& Shikwambana, P. P. (2016). Seasonal variation of the impact of mining activities on Ga-Selati River in Limpopo Province, South Africa. Int. J. Environ. Chem. Ecol. Geol. Geophys. Eng., $10(2), 156-161$. 